\title{
A NEW ASPECT OF AGRICULTURAL UTILIZATION FOR A DESERT AREA IRRIGATED WITH CONTAMINATED INDUSTRIAL WASTEWATER AT ONE OF THE NEW INDUSTRIAL CITIES OF EGYPT
}

\author{
Nader R. Habashy, Atif A. Awadalla* and Mohamed S. A. Ewees* \\ Soils, Water and Environ. Res. Inst., Agric. Res. Center, Giza, Egypt \\ *Soils and Water Dept., Fac. of Agric., Fayoum University, Egypt
}

\section{ABSTRACT:}

The current study is of importance to support the local knowledge, concerning the best use of land and available water resources whether be under demand for agricultural utilization or be planned for later on use. Also, it represents an environmental problem at a new industrial city of El Asher min Ramadan area, i.e., the utilization of contaminated industrial wastewater used as an irrigating source for an adjacent agricultural desert area. In that concerning a hazardous that may cause toxic effects on both crop products and human health. Consequently, it should be executed a suitable soil amendment practices to minimize such possible adverse effects. In this connection, two soil sites are of sandy loam and sandy clay loam texture grades as well as 7 and 13 years land use periods in agricultural utilization, respectively, and directly irrigated with contaminated industrial wastewater after being passed through an oxidation pond were undertaken in this study. These soils are encompassing by the aeolian deposits, and classified as Typic Torriorthents, coarse (soil site 1) or fine loamy (soil site 2), mixed, thermic. According to a parametric evaluation system, they could be evaluated as moderately (S2s1S3s4) and highly suitable (S1s1S3S4) for soil sites 1 and 2, respectively, with an intensity degree for each of soil texture, $\mathrm{CaCO}_{3}$ and gypsum as soil limitations lies in the range of slightmoderate (rating $=90-75)$.

An elemental composition analysis was executed on each of the studied two soil sites, besides the industrial wastewater used for irrigating them, and it was found that available contents of $\mathrm{Fe}, \mathrm{Mn}, \mathrm{Zn}, \mathrm{Cu}, \mathrm{Pb}, \mathrm{Cd}$ and $\mathrm{Ni}$ within the permissible limits, with one exception for $\mathrm{Cd}$ content whose laid at the upper critical limit for soil site 1 and exceeded it in soil site 2 , since the soluble $\mathrm{Cd}$ content in the available irrigation water source is more than the permissible limits. That means both the studied irrigation water source and soils are Cd-polluted ones. Thus, Zn-soil amendment was a matter of concern in this work due to support the antagonism phenomenon between $\mathrm{Cd}$ and $\mathrm{Zn}$ through their uptake by plant roots. Hence, a field experiment was conducted on the chosen two soil sites, where wheat (Triticum astivum, c.v. Giza 163) and barley (Hordeum vulgare, c.v. Giza 126) were sown during the winter season of 2005-2006. The investigated soil plots were irrigated with industrial wastewater in randomized complete block design, with three replicates. The agricultural management practices were conducted as usual. $\mathrm{Zn}$ was applied to soil plots under study at three rates, i.e., 0,5 and $10 \mathrm{~kg} \mathrm{Zn} \mathrm{fed}^{-1}$ in form of zinc sulphate $(22 \% \mathrm{Zn})$ as soil application.

The obtained results showed a beneficial effect of $\mathrm{Zn}$, especially at a high $\mathrm{Cd}$ level on the grown plants. Also, applied $\mathrm{Zn}$ caused more

Fayoum J. Agric. Res. \& Dev., Vol. 21, No.1, January, 2007 
pronounced increments in lengths or dry weights of shoots and the biological yields of wheat and barley crops and their $\mathrm{Zn}$ contents at the expense of $\mathrm{Cd}$. The results revealed also that wheat was more sensitive to both Zn-deficiency and $\mathrm{Cd}$ toxicity as compared to barley. Cadmium toxicity in the shoots was alleviated by $\mathrm{Zn}$ application, but this was not accompanied by corresponding decrease in shoot concentrations of $\mathrm{Cd}$. In addition, increasing $\mathrm{Zn}: \mathrm{Cd}$ in the soils tended to decrease $\mathrm{Cd}$ concentrations in plant organs. It could be deduced that $\mathrm{Zn}$ protected plants from $\mathrm{Cd}$ toxicity by improving plant defense against $\mathrm{Cd}$ - toxicity and its oxidative stress through competing with $\mathrm{Cd}$ for binding to critical cell constituents such as enzymes and membrane protein and lipids.

Key words: Industrial wastewater, desert soils, wheat, barley, Cd-polluted soil and water, Zn-soil amendment.

\section{INTRODUCTION:}

In arid and semi-arid regions the crop production is largely dependent on the availability of water for irrigation. Egypt is one of the regions that depend on the Nile River as the main and almost only source of fresh water. Nowadays, there is still a gap between the available water resources and water needed for agricultural purposes as well as demand for food production. Thus, one of the major policy aims of the Egyptian Government is to attain selfdependence in food production. To achieve this goal efforts have been directed towards increasing the reclaimed new areas using alternative water resources such as drainage, well and industrial wastewaters. The reuse of such water resources may be the only possible choice in irrigating specific locations such as the soils surrounding the new industrial cities at desert areas.

Recently, World face a great problem either in the human health or in the environmental pollution. This problem is more related to the excessive use of mineral or chemical fertilizers as well as the use of low quality water for irrigation, especially in the newly reclaimed desert soils that are suffering from shortage in available water sources. A pronounced amount of released elements, particularly heavy metals, which polluted the biological media of soils and plants grown thereon, and in turn causing possible adverse effects on human and animal health, in addition to environmental risks. Today, there is a renewed interest to find out a suitable technique to avoid the possible hazardous effects of polluted wastewater on soil and plants grown thereon. This target plays also an important role for improving soil productivity as well as increasing crop yields and decreasing the net product contents of such toxic elements (Bhatia et al., 2001).

$\mathrm{Cd}$ is a hazardous heavy metal that may cause toxic effects on both crop production and human health (Wangner, 1993). Although $\mathrm{Cd}$ is not an essential mineral nutrient, it is very easily taken up by plant root and accumulates in plans at concentrations that create risks in the food chain. Accumulation of $\mathrm{Cd}$ in plant tissues can also be toxic at a cellular level, limiting growth and development. Prevention of Cd uptake by plant roots is, therefore, an important strategy to minimize the adverse biological effects of Cd (McLaughlin et al., 1999).

Generally, Zn-applications decrease Cd uptake and accumulation in plants (McLaughlin et al., 1994 and Oliver et al., 1997). Hart et al. (2002) attributed the competivity interaction between $\mathrm{Cd}$ and $\mathrm{Zn}$ for uptake to existence of common transport system on the plasma membranes. Gomes et

Fayoum J. Agric. Res. \& Dev., Vol. 21, No.1, January, 2007 
A NEW ASPECT OF AGRICULTURAL UTILIZATION FOR............ 3 al., (2002) showed that uptake of $\mathrm{Cd}$ is mediated through a $\mathrm{Zn}$-transporter protein across the plasma membrane of yeast cell. Zinc was shown also to interfere with phloem-mediated $\mathrm{Cd}$ transport in wheat, possibly by competing with $\mathrm{Cd}$ for binding sites of a common transport protein on the plasma membranes of sieve tube cells (Clarke et al., 2002).

Nan et al., (2002) showed that increases in Cd application enhanced $\mathrm{Zn}$ concentration in wheat or vice versa. Recently, Wu and Zhang (2002) found that increasing $\mathrm{Zn}$ application could alleviate Cd toxicity stress in barley plants by improving growth and reducing membrane damage. More recently, Habashy and Abo-Zied (2005) stated that shoot dry matter of onion plant decreased with increasing $\mathrm{Cd}$ and gradually increases for $\mathrm{Cd}$ contents with increasing $\mathrm{Cd}$ levels added to soil through the used irrigation eaters.

The current work was carried out an environmental problem at a new industrial city of El Asher min Ramadan area, i.e., the utilization of contaminated industrial wastewater used as an irrigating source for an adjacent agricultural desert area. In addition, this study aimed at identifying the positive effect of zinc application to soil on avoiding the possible adverse effects of Cd-toxicity on plant growth, $\mathrm{Zn}$ deficiency, $\mathrm{Cd}$ toxicity and both $\mathrm{Zn}$ and $\mathrm{Cd}$ concentrations in wheat and barley plants grown on soils irrigated with Cd-polluted wastewater.

\section{MATERIALS AND METHODS:}

\section{a. Materials:}

Two soil sites of about 7 and 13 years land use periods in agricultural utilization, and directly irrigated with contaminated industrial wastewater after being passed through an oxidation pond, Fig. (1). The chemical analysis conducted herein and illustrated thereafter showed that both the studied soil sites and the industrial wastewater used for irrigating them are of available heavy metal contents ( $\mathrm{Fe}, \mathrm{Mn}, \mathrm{Zn}, \mathrm{Cu}, \mathrm{Pb}, \mathrm{Cd}$ and $\mathrm{Ni}$ ) within the permissible limits, with one exception for $\mathrm{Cd}$ content whose laid at the upper critical limit for soil site 1 and exceeded it in soil site 2, since the soluble Cd content in the available irrigation water source is more than the permissible limits. That means both the studied irrigation water source and soils are Cd-polluted ones, as shown in Table (1).

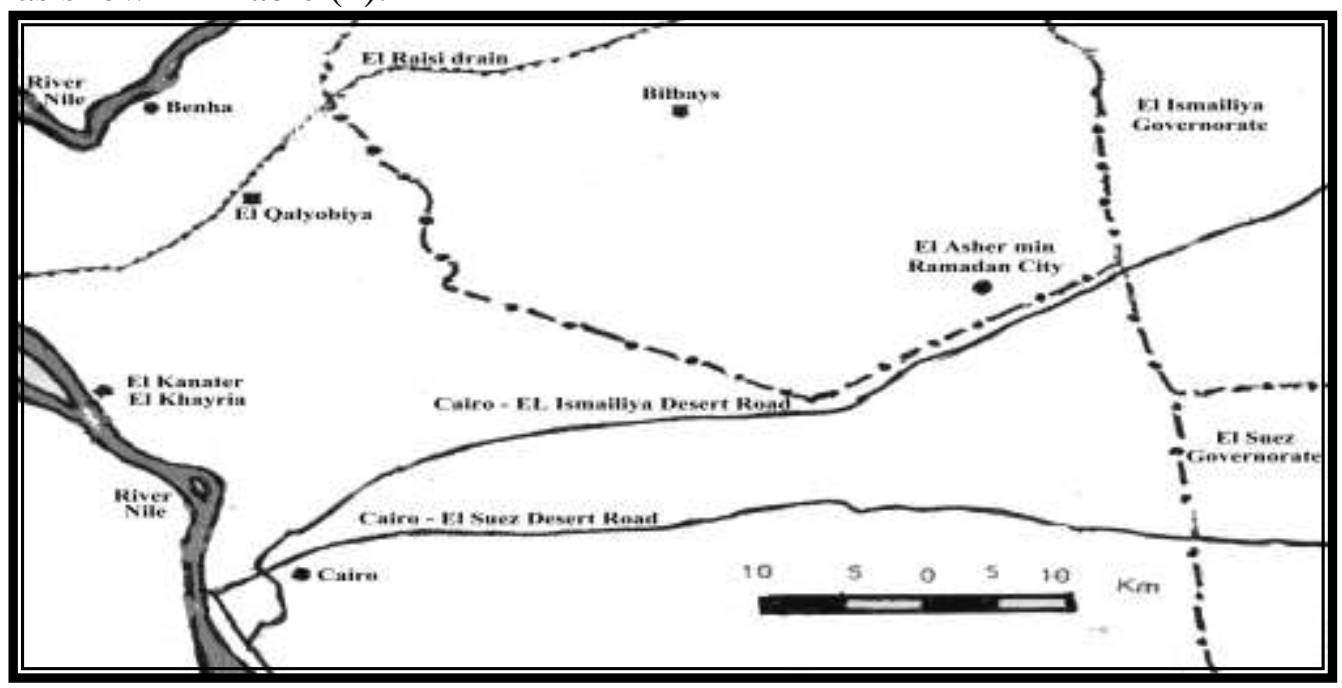

Fig. (1): location map of the studied experimental soils.

Fayoum J. Agric. Res. \& Dev., Vol. 21, No.1, January, 2007 
Nader R. Habashy, et al.

Table (1): Available ( $\mathrm{mg} / \mathrm{kg})$ and soluble $(\mathrm{mg} / \mathrm{L})$ contents of heavy metals in the studied soils and the used irrigation water, respectively.

\begin{tabular}{|c|c|c|c|c|c|c|}
\hline \multicolumn{4}{|c|}{ Essential micronutrients } & \multicolumn{3}{|c|}{ Non essential micronutrients } \\
\hline $\mathrm{Fe}$ & $\mathrm{Mn}$ & $\mathrm{Zn}$ & $\mathrm{Cu}$ & $\mathrm{Pb}$ & $\mathrm{Ni}$ & $\mathrm{Cd}$ \\
\hline \multicolumn{7}{|c|}{ Soil site No. 1} \\
\hline 17.95 & 7.23 & 3.52 & 2.08 & 3.74 & 0.72 & 0.46 \\
\hline \multicolumn{7}{|c|}{ Soil site No. 2} \\
\hline 31.06 & 19.68 & 5.87 & 4.54 & 5.92 & 1.03 & 0.93 \\
\hline \multicolumn{7}{|c|}{ Critical limits of elements $(\mathrm{mg} / \mathrm{kg})$ according to $*$} \\
\hline $66.0-75.0$ & $14.2-38.9$ & $2.6-9.6$ & $1.9-7.8$ & $4.8-15.4$ & $0.3-1.2$ & $0.57-0.79$ \\
\hline \multicolumn{7}{|c|}{ Available irrigation water resource } \\
\hline 3.26 & 0.19 & 0.17 & 0.18 & 2.53 & 0.13 & 0.12 \\
\hline \multicolumn{7}{|c|}{ Recommended maximum concentration of trace elements $(\mathrm{mg} / \mathrm{L})$ according to FAO (1992) } \\
\hline 5.00 & 0.20 & 0.20 & 0.20 & 5.00 & 0.20 & 0.05 \\
\hline
\end{tabular}

* According to the background levels of heavy metals in soils reported by Rashad et al. (1995) for Zn, Ramadan (1995) for Cd, Abu El Roos et al. (1996) for Ni, Rabie et al. (1996) for Fe, $\mathrm{Mn} \& \mathrm{~Pb}$ and Salem (2002) for $\mathrm{Cu}$.

\section{b. Experimental work:}

Thus, $\mathrm{Zn}$-soil amendment was a matter of concern in this work due to support the antagonism phenomenon between $\mathrm{Cd}$ and $\mathrm{Zn}$ and to minimize $\mathrm{Cd}$ uptake by plant roots, and in turn controlling the possible adverse effects of $\mathrm{Cd}$ toxicity. Hence, a field experiment was conducted on the chosen two soil sites, where wheat (Triticum astivum, c.v. Giza 163) and barley (Hordeum vulgare, c.v. Giza 126) were sown during the winter season of 2005-2006. The investigated soil plots were irrigated with industrial wastewater in randomized complete block design, with three replicates. The agricultural management practices were conducted as usual. Zn was applied to soil plots under study at three rates, i.e., 0 , 5 and $10 \mathrm{~kg} \mathrm{Zn} \mathrm{fed}^{-1}$ in form of zinc sulphate $(22 \% \mathrm{Zn})$ as soil application.

The wheat and barley seeds were sown on mid-November 2005 in fixed plots for both the two studied soil sites, with an area of $10.5 \mathrm{~m}^{2}(3 \times 3.5 \mathrm{~m})$ for each one. All wheat and barley plots received nitrogen at a rate of $110 \mathrm{~kg} \mathrm{fed}^{-1}$ as ammonium sulphate $(20.6 \% \mathrm{~N})$, and applied in five equal doses added every two weeks starting from planting; $30 \mathrm{~kg} \mathrm{fed}^{-1} \mathrm{P}_{2} \mathrm{O}_{5}$ as superphosphate $\left(15 \% \mathrm{P}_{2} \mathrm{O}_{5}\right)$ and $24 \mathrm{~kg} \mathrm{fed}^{-1} \mathrm{~K}_{2} \mathrm{O}$ as potassium sulphate $\left(48 \% \mathrm{~K}_{2} \mathrm{O}\right)$ before planting.

\section{c. Methods of analyses:}

The different analyses of the experimental soils, irrigation water source and plants were conducted according to the standard methods outlined by Black et al., (1965) and Page et al., (1982). The studied available micronutrients and heavy metals (Fe, $\mathrm{Mn}, \mathrm{Zn}, \mathrm{Cu}, \mathrm{Pb}, \mathrm{Cd}, \mathrm{B}$ and $\mathrm{Ni}$ ) in soil were extracted using ammonium bicarbonate DTPA were determined according to Soltanpour and Schwab (1977), and their contents in soil solution and available irrigation water were measured using the Atomic Absorption Spectrophotometer.

Concerning the plant analysis, after 60 days from planting (elongation stage) some plants were selected and dried at $70 \mathrm{C}^{\circ}$ for determining their dry weights. Then, the plants were mixed to form composite samples and ground using a micro-mill grinder and subjected to a wet digestion with $\mathrm{H}_{2} \mathrm{SO}_{4}$ and $\mathrm{H}_{2} \mathrm{O}_{2}$ according to Parkinson and Allen (1975) to determine $\mathrm{Fe}, \mathrm{Mn}, \mathrm{Zn}, \mathrm{Cd}$

Fayoum J. Agric. Res. \& Dev., Vol. 21, No.1, January, 2007 
A NEW ASPECT OF AGRICULTURAL UTILIZATION FOR.......... 5 and $\mathrm{Cu}$, which their contents were measured by the Atomic Absorption Spectrophotometer. At harvest, the grain and straw yield were recorded as well as their $\mathrm{Zn}$ and $\mathrm{Cd}$ contents were determined for both cultivated wheat and barley crops according to the former procedures. Least significant difference (L.S.D.) was used to compare among the main treatments and interaction effects at 0.05 according to Snedecor and Cochran (1980).

\section{RESULTS AND DISCUSSIONS:}

Soil is reliable for several modifications through various environmental conditions. So, to identify the adverse effective roles of soil productivity limitations and their intensity in the area under consideration, the obtained results and their discussions will be based on the associated changes in some soil characteristics as affected by their origins under the prevailing environmental conditions. The later conditions include the available water resources and their suitability for the agricultural irrigation purposes, particularly under arid and semi arid features.

\section{A general view on the experimental soils and irrigation water: \\ a. Experimental soils:}

The chosen soil site is occupying the desert formations that are adjacent to the eastern portion of the Nile Delta region. Field studies as illustrated in Table (2), indicate that the studied soils developed on the aeolian deposits (Ibrahim, 2004), which are characterized by topographic features of almost flat for the cultivated areas and gently undulating for the barren ones that devoid natural vegetation in few scattered small patches.

Table (2): The main field morphological features of the studied soil profiles.

\begin{tabular}{|c|c|c|c|c|c|c|c|c|c|c|c|c|}
\hline \multirow{2}{*}{ 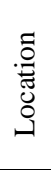 } & \multirow{2}{*}{$\begin{array}{l}\text { Land- } \\
\text { use } \\
\text { period } \\
\text { (years) }\end{array}$} & \multirow{2}{*}{ 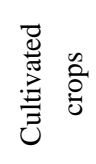 } & \multirow{2}{*}{$\begin{array}{l}\dot{0} \\
\dot{z} \\
0 \\
0 \\
0 \\
0\end{array}$} & \multirow{2}{*}{$\begin{array}{c}\text { Depth } \\
(\mathrm{cm})\end{array}$} & \multicolumn{2}{|c|}{ Soil colour } & \multirow{2}{*}{ 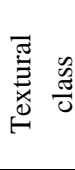 } & \multirow{2}{*}{ 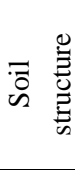 } & \multicolumn{3}{|c|}{ Soil consistence } & \multirow{2}{*}{ 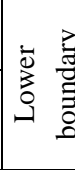 } \\
\hline & & & & & Hue & $\begin{array}{l}\text { Value/ } \\
\text { chroma }\end{array}$ & & & Dry & Moist & Wet & \\
\hline \multirow{6}{*}{ 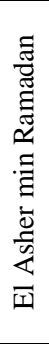 } & \multirow{3}{*}{7} & \multirow{6}{*}{$\begin{array}{c}\text { Wheat } \\
\text { and } \\
\text { barley }\end{array}$} & \multirow{3}{*}{1} & $0-25$ & $10 \mathrm{YR}$ & $4 / 3$ & sl & $\mathrm{cr}$ & sha & vfr & nstpl & -- \\
\hline & & & & $25-70$ & $10 \mathrm{YR}$ & $5 / 6$ & 1s & $\mathrm{sg}$ & so & lo & nstpl & $\mathrm{ds}$ \\
\hline & & & & $\begin{array}{c}70- \\
150\end{array}$ & $10 \mathrm{YR}$ & $7 / 6$ & $\mathrm{~s}$ & $\mathrm{sg}$ & so & lo & nstpl & gs \\
\hline & \multirow{3}{*}{13} & & \multirow{3}{*}{2} & $0-30$ & $5 \mathrm{YR}$ & $5 / 6$ & $\mathrm{scl}$ & $\mathrm{cr}$ & sha & fr & sstpl & -- \\
\hline & & & & $30-80$ & $5 \mathrm{YR}$ & $5 / 8$ & sl & $\mathrm{cr}$ & sha & $\mathrm{fr}$ & nstpl & cs \\
\hline & & & & $\begin{array}{l}80- \\
150\end{array}$ & $5 \mathrm{YR}$ & $5 / 8$ & sl & $\mathrm{cr}$ & sha & $\mathrm{fr}$ & nstpl & ds \\
\hline
\end{tabular}

Soil texture: $\mathrm{s}=\mathrm{sand}, \mathrm{ls}=$ loamy sand, $\mathrm{sl}=\mathrm{sandy}$ loam and $\mathrm{scl}=\mathrm{sandy}$ clay lom.

Soil structure: $\mathrm{sg}=$ single grain, $\mathrm{cr}=\mathrm{crumb}$ and gr=granular.

Soil consistence: Dry: so=soft and sha=slightly hard.

Moist: lo=loose, vfr=very friable and fr=friable.

Wet: nstpl=not sticky \& not plastic and sstpl=slightly sticky \& slightly plastic.

Boundary: gs=gradual smooth, ds=diffuse smooth and cs=clear smooth.

The representative soil profiles Nos. 1 and 2 are, morphologically, characterized by deep soil and lacking for sufficient drainage system. Soil represented by profile 1 was lacking for any evidence of soil development, whereas soil profile 2 was characterized by the occurrence of few dark reddish brown mottles $(2.5 \mathrm{YR} 4 / 4)$ in the uppermost oxidized zone of that profile is probably due to the high content of $\mathrm{Fe}$ in the used industrial irrigation

Fayoum J. Agric. Res. \& Dev., Vol. 21, No.1, January, 2007 
Nader R. Habashy, et al.

wastewater. Also, soil represented by profile 1 is mainly characterized by loose sand to sandy loam texture, whereas whose represented by profile 2 are characterized by scattered small patches of relatively fine textured materials (sandy clay loam) in topsoil. In general, the later condition is probably due to soil management practices through the relatively long-term use period of 13 years, which led to increase in both organic matter and inorganic fine materials (clayey tafla). The cultivated soils on a relatively long-term use have deep root zone, lacking feature of development such as dark yellowish brown matrix colour and modified soil structure (granular and crumb), and in turn a suitable air-moisture regime for biological activity.

In addition, data obtained in Table (3) reveal that the values of bulk density were relatively high due to the relatively coarse nature of soils. However, it seemed that intensive cropping pattern and agro-management practices caused a pronounced reduction in soil bulk density values as shown by layers of soil represented by profile 2 . With respect to total aggregate, data reveal that the their percentage tended also to increase in the relatively fine textured soils developed on soil site 2 vs a pronounced decrease in their values in the loose sand soil of profile 1.

Table (3): Some physical properties of the experimental soils.

\begin{tabular}{|c|c|c|c|c|c|c|c|c|c|}
\hline \multirow{2}{*}{$\begin{array}{l}\text { Prof. } \\
\text { No. }\end{array}$} & \multirow{2}{*}{$\begin{array}{l}\text { Depth } \\
(\mathrm{cm})\end{array}$} & \multicolumn{3}{|c|}{$\begin{array}{c}\text { Particle size } \\
\text { distribution\% }\end{array}$} & \multirow[t]{2}{*}{ Texture class } & \multirow{2}{*}{$\begin{array}{c}\text { Bulk } \\
\text { density } \\
\left(\mathrm{g} / \mathrm{cm}^{3}\right) \\
\end{array}$} & \multirow{2}{*}{$\begin{array}{c}\text { Total } \\
\text { aggregate } \\
\% \\
\end{array}$} & \multirow{2}{*}{$\begin{array}{l}\text { Ksat. } \\
(\mathrm{cm} / \mathrm{h})\end{array}$} & \multirow{2}{*}{$\begin{array}{c}\text { Avail. } \\
\text { water } \%\end{array}$} \\
\hline & & Sand & Silt & Clay & & & & & \\
\hline \multirow{3}{*}{1} & $0-25$ & 71.5 & 13.8 & 14.7 & Sandy loam & 1.49 & 16.95 & 6.97 & 12.85 \\
\hline & $25-75$ & 78.7 & 12.8 & 8.5 & Loamy sand & 1.60 & 7.20 & 9.17 & 9.01 \\
\hline & $75-150$ & 90.5 & 5.7 & 3.8 & Sand & 1.68 & 3.45 & 12.08 & 7.24 \\
\hline \multirow{3}{*}{2} & $0-30$ & 49.3 & 18.2 & 22.5 & Sand clay loam & 1.33 & 21.07 & 3.15 & 15.13 \\
\hline & $30-80$ & 62.1 & 24.3 & 13.6 & Sandy loam & 1.47 & 13.23 & 5.75 & 11.79 \\
\hline & $80-150$ & 71.9 & 16.8 & 11.3 & Sandy loam & 1.58 & 9.93 & 4.89 & 9.97 \\
\hline
\end{tabular}

Moreover, the distinct pattern of saturated hydraulic conductivity was controlled by soil texture and the occurrence of soil conductive pores in both the studied soil sites. The latter condition could be attributed to soil aggregates content and their stability, this is more related to soil structure which modified from single grain to granular and crumb. In addition, a parallel increase in soil available moisture range was proportionally related to the relatively fine texture, which result in an increase for water holding pores and hence increasing ability of soil to retain water.

As a general view, data in Table $(4 \mathrm{a} \& \mathrm{~b})$ indicate that the values of $\mathrm{CaCO}_{3}$, gypsum, organic matter, ESP and ECe in the studied soils were relatively low. Therefore, these soils are classified as poorer in the inorganic and organic colloids, as well as, non-saline and non-alkaline soils (ECe < 4 $\mathrm{dS} / \mathrm{m}$ and ESP $<15)$. 
A NEW ASPECT OF AGRICULTURAL UTILIZATION FOR.

Table (4): Some chemical properties of the experimental soils.

a. Chemical analysis of soil paste extract.

\begin{tabular}{|c|c|c|c|c|c|c|c|c|c|c|}
\hline \multirow{2}{*}{$\dot{0}$} & \multirow{2}{*}{$\begin{array}{l}\text { Depth } \\
(\mathrm{cm})\end{array}$} & \multirow{2}{*}{$\begin{array}{c}\text { Soil pH } \\
(1: 2.5)\end{array}$} & \multirow{2}{*}{$\begin{array}{c}\mathrm{ECe} \\
(\mathrm{dS} / \mathrm{m})\end{array}$} & \multicolumn{7}{|c|}{ Soluble ions $\left(\mathrm{m} \mathrm{mol}_{\mathrm{c}} \mathrm{L}^{-1}\right)$} \\
\hline & & & & $\mathrm{Ca}^{2+}$ & $\mathrm{Mg}^{2+}$ & $\mathrm{Na}^{+}$ & $\mathrm{K}^{+}$ & $\mathrm{HCO}_{3}^{-{ }^{-}}$ & $\mathrm{Cl}^{-}$ & $\mathrm{SO}_{4}{ }^{2-}$ \\
\hline \multirow{3}{*}{1} & $0-25$ & 7.28 & 1.53 & 5.05 & 2.76 & 7.30 & 0.35 & 2.45 & 8.16 & 4.85 \\
\hline & $25-75$ & 7.32 & 1.32 & 4.42 & 1.97 & 6.70 & 0.22 & 2.53 & 6.71 & 4.07 \\
\hline & $75-150$ & 7.41 & 0.95 & 3.08 & 1.53 & 4.87 & 0.15 & 2.98 & 4.05 & 2.60 \\
\hline \multirow{3}{*}{2} & $0-30$ & 7.13 & 2.76 & 10.25 & 5.27 & 12.22 & 0.43 & 2.67 & 16.17 & 8.90 \\
\hline & $30-80$ & 7.20 & 2.43 & 8.96 & 4.51 & 11.00 & 0.30 & 2.05 & 15.94 & 6.48 \\
\hline & $80-150$ & 7.26 & 1.85 & 6.87 & 3.59 & 8.00 & 0.24 & 2.16 & 10.63 & 5.91 \\
\hline
\end{tabular}

b. $\mathrm{CaCO}_{3}$, gypsum and organic matter contents and ESP values.

\begin{tabular}{|c|c|c|c|c|c|}
\hline $\begin{array}{c}\text { Profile } \\
\text { No. }\end{array}$ & $\begin{array}{c}\text { Depth } \\
(\mathrm{cm})\end{array}$ & $\begin{array}{c}\mathrm{CaCO}_{3} \\
\%\end{array}$ & Gypsum \% & $\begin{array}{c}\text { Organic } \\
\text { matter } \%\end{array}$ & ESP \\
\hline \multirow{3}{*}{1} & $0-25$ & 1.28 & 0.09 & 0.41 & 4.92 \\
\cline { 2 - 6 } & $25-70$ & 0.89 & 0.13 & 0.27 & 3.05 \\
\cline { 2 - 6 } & $70-150$ & 0.65 & 0.18 & 0.08 & 2.56 \\
\hline \multirow{3}{*}{2} & $0-30$ & 1.15 & 0.17 & 0.78 & 7.84 \\
\cline { 2 - 6 } & $30-80$ & 1.03 & 0.18 & 0.45 & 5.72 \\
\cline { 2 - 6 } & $80-150$ & 0.96 & 0.21 & 0.29 & 4.95 \\
\hline
\end{tabular}

The taxonomic units of the current experimental soils are identified and named according the obtained results of soil morphological and physiochemical characteristics at the family level according to Soil Survey Staff (1999) as Typic Torriorthents, coarse loamy, mixed, thermic and Typic Torriorthents, fine loamy, mixed, thermic for soil profiles 1 and 2, respectively.

According to a parametric system undertaken by Sys and Verheye (1978), the intensity degrees of soil limitations and suitability categories for the studied soil were calculated and presented in Table (5). It is cleared from data obtained that soil texture (s1), $\mathrm{CaCO}_{3}(\mathrm{~s} 3)$ and gypsum (s4) are the most effective limitations for soil productivity. Also, the studied soils could be evaluated as moderately ( 2 2s1s3s4) and highly ( 1 1s1s3s4) suitable, with an intensity degree for each of soil texture, $\mathrm{CaCO}_{3}$ and gypsum as soil limitations lies in the range of slight-moderate (rating $=90-75)$.

Table (5): Soil limitations and rating indices for evaluating the studied soils at the current experiment.

\begin{tabular}{|c|c|c|c|c|c|c|c|c|c|c|}
\hline \multirow[b]{2}{*}{$\begin{array}{l}\dot{0} \\
0 \\
0 \\
0 \\
0 \\
0\end{array}$} & \multirow[b]{2}{*}{ 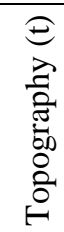 } & \multirow[b]{2}{*}{$\begin{array}{l}\hat{3} \\
0 \\
0 \\
0 \\
0 \\
3\end{array}$} & \multicolumn{4}{|c|}{$S$} & \multirow[b]{2}{*}{ 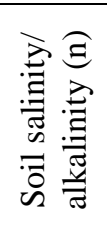 } & \multirow[b]{2}{*}{ 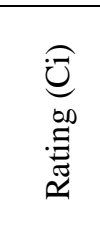 } & \multirow[b]{2}{*}{ 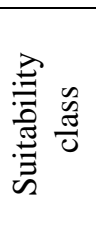 } & \multirow[b]{2}{*}{ 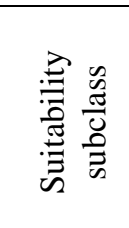 } \\
\hline & & & 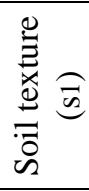 & 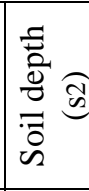 & $\int_{\tilde{U}}^{\infty} \widehat{\infty}$ & 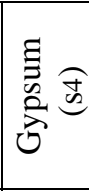 & & & & \\
\hline 1 & 100 & 100 & 75 & 100 & 95 & 90 & 100 & 64.13 & $\mathrm{~S} 2$ & $\mathrm{~S} 2 \mathrm{~s} 1 \mathrm{~s} 3 \mathrm{~s} 4$ \\
\hline 2 & 100 & 100 & 95 & 100 & 95 & 90 & 100 & 81.23 & $\mathrm{~S} 1$ & S1s1s3s 4 \\
\hline
\end{tabular}

Fayoum J. Agric. Res. \& Dev., Vol. 21, No.1, January, 2007 
b. Irrigation water:

According to the water salinity and sodicity classes undertaken by Ayers and Westcot (1985), data in Table (6) indicate that the used industrial wastewater, as an irrigation source, lies in the category of $\mathrm{C}_{2} \mathrm{~S} 1$.

Table (6): Chemical characteristics of the used industrial wastewater.

\begin{tabular}{|l|c|}
\hline \multicolumn{1}{|c|}{ Water characteristics } & Value \\
\hline $\mathrm{PH} \quad\left(\mathrm{dS} \mathrm{m}^{-1}\right)$ & 7.12 \\
\hline ECiw & 1.61 \\
\hline Total dissolved salts $\left(\mathrm{mg} \mathrm{L}^{-1}\right)$ & 1030.40 \\
\hline Soluble ions $\left(\mathrm{m} \mathrm{mol}_{\underline{c}}{\underline{L^{-1}}}^{-1}\right.$ & \\
$\mathrm{Ca}^{{ }^{+}}$ & 5.13 \\
$\mathrm{Mg}^{++}$ & 2.87 \\
$\mathrm{Na}^{+}$ & 7.50 \\
$\mathrm{~K}^{+}$ & 0.56 \\
$\mathrm{CO}_{3}^{--}$ & 0.00 \\
$\mathrm{HCO}_{3-}$ & 1.96 \\
$\mathrm{Cl}^{-}$ & 5.78 \\
$\mathrm{SO}_{4}^{--}$ & 8.32 \\
\hline Boron content (mg/L) & 0.48 \\
\hline Sodium adsorption ratio (SAR) & 3.95 \\
\hline Residual sodium carbonate (RSC) & 0.00 \\
\hline Irrigation water suitability degree & $\mathrm{C} 2 \mathrm{~S} 1$ \\
\hline
\end{tabular}

This is due to the ECiw and SAR values lay within the range of $>0.75$ $\mathrm{dS} / \mathrm{m}$ and $<6.00$, respectively.

Usage of such heavy metals polluted industrial wastewater is one of the additional developments, especially in such new industrial city of El Asher min Ramadan area to accelerate the direction towards agricultural utilization of the adjacent desert areas through the National Policy of Local Government. Such agricultural utilization can be grown as a supplemental aspect to cover some agricultural needs for local production of human consumption and animal feeding. In spite of such irrigation water source is $\mathrm{Cd}$-polluted one, $\mathrm{Cd}$ as a heavy metal is not an essential nutrient, but it is very easily taken up by plant root and accumulates in plans at toxic concentrations. Thus, prevention of $\mathrm{Cd}$ uptake by plant roots is, therefore, an important strategy to minimize its adverse biological effects.

\section{Effect of Zn-soil amendment vs Cd-polluted soil on leaf symptoms and the shoot dry weights:}

a. Zn leaf symptoms:

Irrespective of Cd-polluted soil vs Zn deficiency in plants grown on the control treatment of 13 years land use period, it was noticed an occurrence of necrotic spots on youngest leaves and severe reduction in shoot lengths. The leaf symptoms of $\mathrm{Zn}$ deficiency were intensified when $\mathrm{Cd}$ occurred at a level more than the permissible limits as well as they are more cleared or more severe in wheat than in barley. It is noteworthy that adding $\mathrm{Zn}$ at 5 and $10 \mathrm{~kg}$ fed $^{-1}$ to Cd-polluted soils of 7 and 13 years land use periods alleviated the severity of Cd toxicity leaf symptoms on both the grown wheat and barley

Fayoum J. Agric. Res. \& Dev., Vol. 21, No.1, January, 2007 
A NEW ASPECT OF AGRICULTURAL UTILIZATION FOR.

plants grown, The effect seemed more obvious at the higher rate of $\mathrm{Zn}$ application.

\section{b. Shoot dry weights:}

At the elongation stage, $\mathrm{Zn}$ deficiency caused also severe inhibition in shoots growth. Such a deficiency is due to the increase in Cd content in soil, and in turn $\mathrm{Zn}$ deficient resulted in decreasing shoot dry weights, as shown in Table (7).

Table (7): Effect of $\mathrm{Zn}$-soil amendment on shoot dry weights at the elongation stage of both wheat and barley plants grown on Cd-polluted soils.

\begin{tabular}{|c|c|c|c|c|c|c|}
\hline \multirow{3}{*}{$\begin{array}{l}\text { Zn treatment } \\
\quad(\mathrm{kg} / \mathrm{fed})\end{array}$} & \multicolumn{6}{|c|}{ Shoot dry weights (g/plant) } \\
\hline & \multicolumn{3}{|c|}{ Wheat } & \multicolumn{3}{|c|}{ Barley } \\
\hline & 7 years & 13 years & Mean & 7 years & 13 years & Mean \\
\hline Control (0) & 2.18 & 1.67 & 1.93 & 2.51 & 1.96 & 2.24 \\
\hline 5 & 4.36 & 3.60 & 3.98 & 5.80 & 4.53 & 5.17 \\
\hline 10 & 6.41 & 5.22 & 5.97 & 8.13 & 6.38 & 7.26 \\
\hline Mean & 4.32 & 3.60 & 3.96 & 5.48 & 4.29 & 4.89 \\
\hline \multicolumn{7}{|c|}{ Statistical analysis } \\
\hline \multirow{3}{*}{ L.S.D. at 0.05} & \multicolumn{2}{|c|}{ Land use period } & 0.62 & \multicolumn{2}{|c|}{ Land use period } & 0.56 \\
\hline & \multicolumn{2}{|l|}{$\mathrm{Zn}$} & 1.23 & \multicolumn{2}{|l|}{$\mathrm{Zn}$} & 2.32 \\
\hline & \multicolumn{2}{|c|}{ Period x Zn } & 1.52 & \multicolumn{2}{|c|}{ Period x Zn } & 3.51 \\
\hline
\end{tabular}

The greatest reductions in shoot dry weights were more distinct and more pronounced in soil of the highest $\mathrm{Cd}$ level, i.e., of thirteen years land use period, cultivated with wheat plants and irrigated with Cd-polluted industrial wastewater. As for plants grown on both Cd-polluted soils of 7 and 13 years land use periods and treated with $10 \mathrm{~kg} \mathrm{fed}^{-1}$, data in Table (7) showed that their shoot dry weights were positively affected and significantly increased. This increase occurred in both crop plants under study, particularly the barley plants. These results indicate a greater sensitivity of wheat plants to both $\mathrm{Zn}$ deficiency and Cd-toxicity as compared with barely ones.

\section{Effect of Zn-soil amendment vs Cd-polluted soil on grain and straw yields of wheat and barley plants:}

Data in Table (8) reveal that there was a greater reduction in the grain yields of both wheat and barley plants grown on the soil of 13 years land use period as compared with those grown on the soil of 7 years land use one and irrigated with industrial wastewater in absence of $\mathrm{Zn}$ application (the control treatment). Straw yields were also negatively affected by $\mathrm{Cd}$ contents, which exceeded the permissible limits in soil. This is mainly due to an evidence of significantly diminution of shoot lengths, and in turn their dry weights as a result of $\mathrm{Cd}$ inhibition.

McGrath et al. (1995) observed a significant decrease of clover biomass production grown on $\mathrm{Cd}$ polluted soil. The presence of $\mathrm{Cd}$ in the soil may significantly affect the shoot lengths. It is noteworthy to indicate that both grain and straw yields of barley exhibited relatively increases as compared with those of wheat. This condition is emphasized the sensitivity of wheat to Cd-pollution in both irrigation water and soil media. Application of $\mathrm{Zn}$ at 5 and $10 \mathrm{~kg} \mathrm{fed}^{-1}$ as soil amendment increased both grain and straw yields of wheat and barley crops. This can be explained on the fact that $\mathrm{Zn}$ significantly

Fayoum J. Agric. Res. \& Dev., Vol. 21, No.1, January, 2007 
Nader R. Habashy, et al.

alleviated $\mathrm{Cd}$ transport to shoots of plants and provided potential improved protection from soil Cd risks (Green $\boldsymbol{e t}$ al., 2003).

IV. Effect of Zn-soil amendment vs Cd-polluted soil on Cd \& Zn contents in grain and straw of wheat and barley plants grown on the Cd-polluted soils:

The quantities of $\mathrm{Cd}$ that enter the food chain are important for human health. This heavy metal accumulates in the tissues of vegetables and animals. Its toxicity can occur for human body if leaves become Cd-high level (more than $0.5 \mathrm{Cd} \mathrm{mg} \mathrm{head}^{-1}$ week $^{-1}$, which is the accepted limit of FAO-WHO). Codex Alimentarius (a part of FAO/WHO) is considering placing a limit of $0.1 \mathrm{mg}$ $\mathrm{kg}^{-1}$ fresh weight as a permissible content for cereal grains (Bailey et al., 1996).

Table (8): Effect of $\mathrm{Zn}$-soil amendment on grain and straw yields of wheat and barley plants grown on Cd-polluted soils.

\begin{tabular}{|c|c|c|c|c|c|c|}
\hline \multicolumn{7}{|c|}{ Biological yield of wheat (ton/fed) } \\
\hline \multirow{2}{*}{$\begin{array}{l}\text { Zn treatment } \\
(\mathrm{kg} / \mathrm{fed})\end{array}$} & \multicolumn{3}{|c|}{ Grain yield } & \multicolumn{3}{|c|}{ Straw yield } \\
\hline & 7 years & 13 years & Mean & 7 years & 13 years & Mean \\
\hline Control (0) & 0.67 & 0.53 & 0.60 & 0.89 & 0.72 & 0.81 \\
\hline 5 & 1.04 & 0.91 & 0.98 & 0.93 & 1.57 & 1.75 \\
\hline 10 & 1.76 & 1.17 & 1.42 & 2.46 & 2.02 & 2.24 \\
\hline Mean & 1.13 & 0.87 & 1.00 & 1.76 & 1.44 & 1.60 \\
\hline \multicolumn{7}{|c|}{ Statistical analysis } \\
\hline \multirow{3}{*}{ L.S.D. at 0.05} & \multicolumn{2}{|c|}{ Land use period } & 0.10 & \multicolumn{2}{|c|}{ Land use period } & 0.20 \\
\hline & \multicolumn{2}{|l|}{$\mathrm{Zn}$} & 0.42 & \multicolumn{2}{|l|}{$\mathrm{Zn}$} & 1.05 \\
\hline & \multicolumn{2}{|c|}{ Period x Zn } & 0.21 & \multicolumn{2}{|c|}{ Period x Zn } & 0.92 \\
\hline \multicolumn{7}{|c|}{ Biological yield of barley (ton/fed) } \\
\hline Control (0) & 0.71 & 0.62 & 0.67 & 1.27 & 0.98 & 1.13 \\
\hline 5 & 1.35 & 1.16 & 1.26 & 2.49 & 2.06 & 1.75 \\
\hline 10 & 1.93 & 1.72 & 1.83 & 3.24 & 2.37 & 2.81 \\
\hline Mean & 1.33 & 1.17 & 1.25 & 1.98 & 1.80 & 1.89 \\
\hline \multicolumn{7}{|c|}{ Statistical analysis } \\
\hline \multirow{3}{*}{ L.S.D. at 0.05} & \multicolumn{2}{|c|}{ Land use period } & 0.05 & \multicolumn{2}{|c|}{ Land use period } & 0.08 \\
\hline & \multicolumn{2}{|l|}{$\mathrm{Zn}$} & 0.31 & \multicolumn{2}{|l|}{$\mathrm{Zn}$} & 0.05 \\
\hline & \multicolumn{2}{|c|}{ Period x Zn } & 0.40 & \multicolumn{2}{|c|}{ Period x Zn } & 0.60 \\
\hline
\end{tabular}

\section{a. Cadmium and zinc contents in the biological yield (straw and grain):}

The data obtained in Table (9) show a triple relation among soil available $\mathrm{Cd}$ content, applied $\mathrm{Zn}$-soil amendment and the $\mathrm{Cd}$ and $\mathrm{Zn}$ concentrations in both grain and straw yields of wheat and barely plants grown on the studied soils of 7 and 13 years land use periods under irrigation by Cd-polluted industrial wastewater. These results were true, since Eva Leahoczky et al. (2002) reported that there was a positive linear regression indicated between plants grown on soils with higher $\mathrm{Cd}$ content and higher $\mathrm{Cd}$ concentrations in leaves, stem and roots.

In general, the results obtained indicate that the applied Zn-soil amendment at rates of 5 and $10 \mathrm{~kg} \mathrm{fed}^{-1}$ reduced $\mathrm{Cd}$ concentrations in the biological yields of wheat and barely crops. Also, $\mathrm{Cd}$ content reached the maximum critical permissible limits in the biological yields of wheat and barely crops grown on the untreated soil of 13 years land use period (the control treatment). Moreover, it is noticed that $\mathrm{Cd}$ content was relatively higher in the biological yield of barley as compared with the corresponding wheat, indicating the later crop is more sensitive for Cd-pollution than the former. This means that decreased $\mathrm{Cd}$ uptake may have been caused due to

Fayoum J. Agric. Res. \& Dev., Vol. 21, No.1, January, 2007 
A NEW ASPECT OF AGRICULTURAL UTILIZATION FOR.......... 11 applied $\mathrm{Zn}$, the effect seemed more obvious with the higher rate of the applied $\mathrm{Zn}$. These results are in harmony with those reported by Haghiri (1974) who stated that $\mathrm{Cd}$ and $\mathrm{Zn}$ have similar ion structures and electronegativites although they have different ions radii $\left(\mathrm{Zn}^{2+}=0.07 \mathrm{~nm}\right.$ and $\left.\mathrm{Cd}^{2+}=0.097 \mathrm{~nm}\right)$. The similarity results in an antagonistic relation between $\mathrm{Zn}$ and $\mathrm{Cd}$, where the difference in ions radii facilitates and increases plant selectivity for $\mathrm{Zn}$. The data show also that the repose degree of plants to $\mathrm{Cd}$ and $\mathrm{Zn}$ uptake was probably related to their relative available or soluble contents in soil and irrigation water (Abdel Sabour $\boldsymbol{e t}$ al., 1988). This finding is in agreement with Oliver et al. (1994) who showed that the inhibition of $\mathrm{Cd}$ transport to the shoots might also result in an inhibition of Cd movement to the grain.

Table (9): Effect of applied $\mathrm{Zn}$-soil amendment on $\mathrm{Cd}$ and $\mathrm{Zn}$ contents in grain and straw yields of wheat and barley plants grown on Cd-polluted soils.

\begin{tabular}{|c|c|c|c|c|c|c|}
\hline \multicolumn{7}{|c|}{ Cadmium content $(\mathrm{mg} / \mathrm{kg})$} \\
\hline \multicolumn{7}{|c|}{ Wheat } \\
\hline \multirow{2}{*}{$\begin{array}{l}\text { Zn treatment } \\
(\mathrm{kg} / \mathrm{fed})\end{array}$} & \multicolumn{3}{|c|}{ Grain yield } & \multicolumn{3}{|c|}{ Straw yield } \\
\hline & 7 years & 13 years & Mean & 7 years & 13 years & Mean \\
\hline Control (0) & 1.15 & 1.83 & 1.49 & 1.15 & 1.78 & 1.47 \\
\hline 5 & 0.95 & 1.00 & 0.98 & 0.90 & 0.95 & 0.93 \\
\hline 10 & 0.85 & 0.89 & 0.87 & 0.78 & 0.85 & 0.82 \\
\hline Mean & 0.98 & 1.24 & 1.11 & 0.94 & 1.19 & 1.07 \\
\hline \multicolumn{7}{|c|}{ Statistical analysis } \\
\hline \multirow{3}{*}{ L.S.D. at 0.05} & \multicolumn{2}{|c|}{ Land use period } & 0.07 & \multicolumn{2}{|c|}{ Land use period } & 0.09 \\
\hline & \multicolumn{2}{|l|}{$\mathrm{Zn}$} & 0.04 & \multicolumn{2}{|l|}{$\mathrm{Zn}$} & 0.02 \\
\hline & \multicolumn{2}{|c|}{ Period x Zn } & 0.06 & \multicolumn{2}{|c|}{ Period x Zn } & 0.05 \\
\hline \multicolumn{7}{|c|}{ Barley } \\
\hline Control (0) & 1.19 & 1.95 & 1.57 & 1.30 & 2.05 & 1.63 \\
\hline 5 & 1.15 & 1.21 & 1.18 & 1.00 & 1.10 & 1.05 \\
\hline 10 & 0.98 & 1.07 & 1.03 & 0.86 & 0.95 & 0.91 \\
\hline Mean & 1.11 & 1.41 & 1.26 & 1.02 & 1.00 & 1.01 \\
\hline \multicolumn{7}{|c|}{ Statistical analysis } \\
\hline \multirow{3}{*}{ L.S.D. at 0.05} & \multicolumn{2}{|c|}{ Land use period } & 0.12 & \multicolumn{2}{|c|}{ Land use period } & 0.03 \\
\hline & \multicolumn{2}{|l|}{$\mathrm{Zn}$} & 0.13 & \multicolumn{2}{|c|}{$\mathrm{Zn}$} & 0.10 \\
\hline & \multicolumn{2}{|c|}{ Period x Zn } & 0.05 & \multicolumn{2}{|c|}{ Period x Zn } & 0.08 \\
\hline \multicolumn{7}{|c|}{ Zinc content $(\mathrm{mg} / \mathrm{kg})$} \\
\hline \multicolumn{7}{|c|}{ Wheat } \\
\hline \multirow{2}{*}{$\begin{array}{l}\text { Zn treatment } \\
(\mathrm{kg} / \mathrm{fed})\end{array}$} & & Grain yiel & & & Straw yiel & \\
\hline & 7 years & 13 years & Mean & 7 years & 13 years & Mean \\
\hline Control (0) & 7.0 & 3.0 & 5.0 & 13.0 & 7.0 & 10.0 \\
\hline 5 & 30.0 & 22.0 & 26.0 & 24.0 & 18.6 & 21.0 \\
\hline 10 & 36.0 & 25.0 & 30.5 & 42.0 & 36.0 & 38.0 \\
\hline Mean & 24.3 & 28.0 & 26.2 & 26.3 & 20.5 & 23.4 \\
\hline & & Statis & l analy & & & \\
\hline & Land use & eriod & 2.0 & Land us & beriod & 3.0 \\
\hline L.S.D. at 0.05 & $\mathrm{Zn}$ & & 4.0 & $\mathrm{Zn}$ & & 9.0 \\
\hline & Period $\mathrm{X}$ & & 2.0 & Period $x$ & & 7.0 \\
\hline & & & rley & & & \\
\hline Control (0) & 5.0 & 2.0 & 3.5 & 7.0 & 5.0 & 6.0 \\
\hline 5 & 25.0 & 21.9 & 23.5 & 14.0 & 12.0 & 13.0 \\
\hline 10 & 30.0 & 26.2 & 28.2 & 35.0 & 32.0 & 33.5 \\
\hline Mean & 20.0 & 23.4 & 21.7 & 18.7 & 16.4 & 17.6 \\
\hline & & Statis & l analy & & & \\
\hline & Land use & eriod & 2.0 & Land us & geriod & 3.0 \\
\hline L.S.D. at 0.05 & $\mathrm{Zn}$ & & 3.0 & $\mathrm{Zn}$ & & 0.5 \\
\hline & Period $\mathrm{X}$ & & 2.0 & Period $x$ & & 9.0 \\
\hline
\end{tabular}

Fayoum J. Agric. Res. \& Dev., Vol. 21, No.1, January, 2007 
a. Cadmium/zinc ratios in the biological yield (straw and grain):

Applied Zn-soil amendment, Table (10), resulted in significant reduction in the $\mathrm{Cd} / \mathrm{Zn}$ ratios in straw and grain yields of both wheat and barley crops. However, decreasing $\mathrm{Cd} / \mathrm{Zn}$ due to application of $\mathrm{Zn}$ amendment was more pronounced in the plants grown on the 7 years land use period as compared to those grown on 13 years land use one. It is worthy to mention that the $\mathrm{Cd} / \mathrm{Zn}$ ratios were relatively higher in barley, which is considered to be a $\mathrm{Cd}$ accumulator in both straw and grain yields.

Table (10): Effect of $\mathrm{Zn}$-soil amendment on $\mathrm{Cd} / \mathrm{Zn}$ ratios in grain and straw yields of wheat and barley plants grown on Cd-pollution soils of both two land use periods.

\begin{tabular}{|c|c|c|c|c|c|c|}
\hline \multicolumn{7}{|c|}{$\mathrm{Cd} / \mathrm{Zn}$ ratio } \\
\hline \multicolumn{7}{|c|}{ Wheat } \\
\hline \multirow{2}{*}{$\begin{array}{c}\text { Zn treatment } \\
(\mathrm{kg} / \mathrm{fed})\end{array}$} & \multicolumn{3}{|c|}{ Grain yield } & \multicolumn{3}{|c|}{ Straw yield } \\
\hline & 7 years & 13 years & Mean & 7 years & 13 years & Mean \\
\hline Control (0) & 0.164 & 0.610 & 0.387 & 0.088 & 0.254 & 0.171 \\
\hline 5 & 0.032 & 0.045 & 0.039 & 0.038 & 0.051 & 0.045 \\
\hline 10 & 0.204 & 0.039 & 0.032 & 0.019 & 0.024 & 0.022 \\
\hline Mean & 0.073 & 0.231 & 0.153 & 0.048 & 0.110 & 0.079 \\
\hline \multicolumn{7}{|c|}{ Statistical analysis } \\
\hline \multirow{3}{*}{ L.S.D. at 0.05} & \multicolumn{2}{|c|}{ Land use period } & 0.050 & \multicolumn{2}{|c|}{ Land use period } & 0.030 \\
\hline & \multicolumn{2}{|l|}{$\mathrm{Zn}$} & 0.040 & \multicolumn{2}{|l|}{$\mathrm{Zn}$} & 0.030 \\
\hline & \multicolumn{2}{|c|}{ Period x Zn } & 0.010 & \multicolumn{2}{|c|}{ Period $x \mathrm{Zn}$} & 0.002 \\
\hline \multicolumn{7}{|c|}{ Barley } \\
\hline Control (0) & 0.238 & 0.980 & 0.609 & 0.185 & 0.410 & 0.298 \\
\hline 5 & 0.046 & 0.055 & 0.051 & 0.071 & 0.092 & 0.082 \\
\hline 10 & 0.033 & 0.041 & 0.037 & 0.025 & 0.030 & 0.028 \\
\hline Mean & 0.106 & 0.359 & 0.232 & 0.094 & 0.177 & 0.136 \\
\hline \multicolumn{7}{|c|}{ Statistical analysis } \\
\hline \multirow{3}{*}{ L.S.D. at 0.05} & \multicolumn{2}{|c|}{ Land use period } & 0.090 & \multicolumn{2}{|c|}{ Land use period } & 0.050 \\
\hline & \multicolumn{2}{|l|}{$\mathrm{Zn}$} & 0.020 & \multicolumn{2}{|l|}{$\mathrm{Zn}$} & 0.040 \\
\hline & \multicolumn{2}{|c|}{ Period x Zn } & 0.030 & \multicolumn{2}{|c|}{ Period x Zn } & 0.070 \\
\hline
\end{tabular}

The aforementioned findings are in agreement with those reported by Piret and Kooken (1980) who observed that $\mathrm{Cd} / \mathrm{Zn}$ ratios in plants varied among soils due to the interactions between the two metals when their concentrations in soil were high. On the same trend, date in Table (10) indicate that $\mathrm{Cd}: \mathrm{Zn}$ for wheat and barley at different applied $\mathrm{Zn}$ rates did not show any relation to the $\mathrm{Cd}$ concentrations in shoots. This is because increasing $\mathrm{Zn}$ in the soils competed with $\mathrm{Cd}$ and tended to decrease $\mathrm{Cd}$ uptake and hence its concentrations in plant organs. These results are compatible with a hypothesis of $\mathrm{Zn}$ protected plants from $\mathrm{Cd}$ toxicity by improving plant defense against $\mathrm{Cd}$ induced and its oxidative stress. This is due to competing with $\mathrm{Cd}$ for binding to critical cell constituents such as enzymes and membrane protein and lipids.

Fayoum J. Agric. Res. \& Dev., Vol. 21, No.1, January, 2007 
REFERENCES:

Abdel-Sabour, M.F.; J.J. Mortvedt and J.J. Kelsoe (1988): Cadmiumzinc interactions in plants and extractable cadmium and zinc fractions in soil. Soil Sci., 145: 424-431.

Abu El Roos, S.A.; Sh.Sh. Holah and S.H. Badawy (1996): Background levels of some heavy metals in soils of Egypt and associated corn plant. Egypt. J. Soil Sci., 36: 83-97.

Ayers, R.S. and D.W. Westcot, (1985): Water quality for agriculture, irrigation and drainage. Paper No. 29, FAO, Rome, Italy.

Bailey, L.D.; C.A. Grant and R.J. Hill (1996). Uptake of cadmium by crop plants. In: Proceedings of OECD, Paris, France, pp. 147-179.

Bhatia, A.; H. Pathak and H.C. Joshi (2001): Use of sewage as a source of plant nutrient: potentials and problems. Fert. News, 46 (3): 55-58.

Black, C.A.; D.D. Evans; L.E. Ensminger; J.L. White and F.E. Clark (1965): Methods of Soil Analysis. Amer. Soc. Agron. Inc., Pub., Madison, Wisc., USA.

Clarke, J.M.; W.A. Norvell; F.R. Clarke and W.T. Buckley (2002): Concentration of cadmium and other elements in the grain of nearisogenic durum lines. Can. J. Plant Sci., 82: 27-33.

Eva Lehoczky; IIona Loth and Zsanett Kiss (2002):.Cadmium and lead uptake by white mustard (Sinpis alba L.) grown in different soils. Comm. Soil Sci and Plant Analysis, 33: 3176-3176.

FAO (1992): The use of saline waters for crop production. Land and Water Development Division, FAO, Rome.

Gomes, D.S.; L.C. Fragoso; C.J. Riger; A.D. Panek and E.C.A. Eleutherio (2002): Regulation of cadmium uptake by Saccharomyces cerevisiae. Biochim. Biophys. Acta, 1573: 21-25.

Green, C.E.; R.L. Chaney and J. Bouwkamp (2003): Interactions between cadmium uptake and phytotoxic levels of zinc in hard red spring wheat. J. Plant Nutrition, 26: 417-430.

Habashy, N.R. and M.M.A. Abo-Zied (2005): Impact of CD-PB polluted water on growth and elemental composition of onion plants grown on a calcareous soil inoculated with micorrhizal. Egypt. J. Appl. Sci., 20: 586603.

Haghiri, F. (1974): Plant uptake of cadmium as influenced by cation exchange capacity, organic matter, zinc and soil temperature. J. Environ. Qual., 3: 180-182.

Hart, J.J; R.M. Welch; W.A. Norvell and L.V. Kochian (2002): Transport interactions between cadmium and zinc in roots of bread and durum wheat seedlings. Physiol. Plant, 116: 73-78.

Ibrahim, M.S.M. (2004): Effects of farm practices on soils of East Nile Delta. Ph. D. Thesis, Inst. of Environ. Studies and Res., Ain Shams Univ., Egypt.

McGrath, S.P.; A.M. Chaudir and K.E. Giller (1995): Long-term effected of metals in sewage sludge on soils, micro-organisms and plants. J. Ind. Microbiol., 14: 94-104.

McLaughlin, M.J.; D.R. Parker and J.M. Clarke (1999): Metals and micronutrients-food safety issues. Field Crops Res., 60: 143-163.

McLaughlin, M.J.; L.T. Palmer; K.G.Tiller; T.A. Beech and M.K. Smart (1994): Increased soil salinity causes elevated cadmium concentrations in field-grown potato tubers. J. Environ. Qual., 23: 1013-1018.

Fayoum J. Agric. Res. \& Dev., Vol. 21, No.1, January, 2007 
Nan, Z.R.; J.J. Li; J.M. Zhang and G.D. Cheng (2002): Cadmium and zinc interactions and their transfer in soil-crop system under actual field. Sci. Total Environ., 285: 187-195.

Oliver, D.P.; R. Hannam; K.G.Tiller; N.S. Wilhelm; R.H. Merry and G.D. Cozens (1994): The effects of zinc fertilization on cadmium concentration in wheat grain. J. Environ. Qual., 23: 705-711.

Oliver, D.P.; N.S. Wilhelm; J.D. McFarlane; K.G. Tiller and G.D. Cozens (1997): Effect of soil and foliar applications of zinc on cadmium concentration in wheat grain. Aust. J. Exp. Agricult., 37: 677-681.

Page, A.I. ; R.H. Miller and D.R. Keeney Eds. (1982): Methods of Soil Analysis. Part 2: Chemical and Microbiological Properties. $2^{\text {nd }}$ Edition, Amer. Soc. of Agron., Madison, Wisconsin, U.S.A.

Parkinson, J.A. and S.E. Allen (1975): Ewer oxidation procedure suitable for the determination of nitrogen and mineral nutrients in biological material. Commun. Soil Sci. Plant Analysis, 6: 1-11.

Piret, T. and G. Kooken (1980): Root transfer of cadmium and zinc in carrot in polluted soil. Bull. Soc. R. Bot. Belg., 113:145-152.

Rabie, F.; M.Y. Khader; I.F. Rashad; A.M. Fawzy and W. Hussein (1996): Heavy metals distribution in the different particle sizes of soils irrigated from polluted sources. Egypt. J. Soil Sci., 36: 179-188.

Ramadan, M.A. (1995): Studies on the pollution of the agricultural environment in Egypt. Ph. D. Thesis, Fac. of Agric., Cairo Univ., Egypt.

Rashad, I.F.; A.O. Abd EI Nabi; M.E. El Hemely and M.A. Khalaf (1995): Background levels of heavy metals in the Nile Delta soils. Egypt. J. Soil Sci., 35: 239-252.

Salem, S.Y.M. (2002): Monitoring of environmental pollution for soil and water with some metals and non-metals resulting from fertilizers factories and its remediation. Ph. D. Thesis, Environ. Studies and Res. Inst., Ain Shams Univ. Egypt.

Snedecor, G.W. and W.G. Cochran (1980). Statistical Methods. $7^{\text {th }}$ ed. Iowa State Univ. Press, Iowa, USA.

Soil Survey Staff (1999): Soil Taxonomy. A Basis System of Soil Classification for Making and Interpreting Soil Surveys. Second Edition, U.S. Department of Agriculture, Natural Resources Conservation Service, U.S.D.A., Agriculture Handbook No. 436.

Soltanpour, P.N. and A.B. Schwab (1977): A new soil test for simultaneous extraction of micronutrients in alkaline soils. Comm. Soil Sc. and Plant Annal., 8: 195.

Sys, C. and W. Verheye (1978): An attempt to the evaluation of physical land characteristics for irrigation to the FAO framework for land evaluation. Int. 1, Trai. Cent. Post Grad. Soil Sci., Ghent, Belgium.

Wagner, G.J. (1993): Accumulation of cadmium in crop plants and its consequences to human health. Adv. Agron., 51: 173-212.

Wu, F.B. and G.P. Zhang (2002): Alleviation of cadmium-toxicity by application of zinc and ascorbic acid in barley. J. Plant Nutr., 25: 27452761.

Fayoum J. Agric. Res. \& Dev., Vol. 21, No.1, January, 2007 
A NEW ASPECT OF AGRICULTURAL UTILIZATION FOR.

روية جديدة للتنمية الزراعية فى منطقة صحراوية تروي بمياه صرف ملوثة بمخلفات المصانع في إحدي

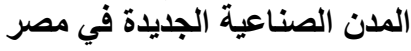

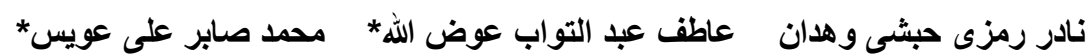

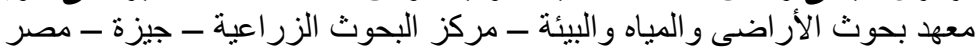

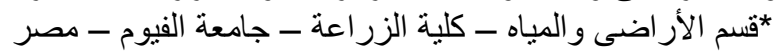

تعتبر نتائج هذه الدر اسة من الأهمية لتدعيم المعلومات المحلية والتى تختص بأفضل إستخدام لكل من التصن

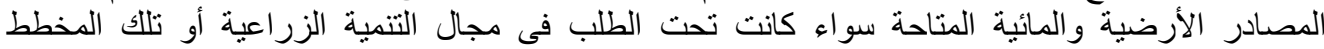

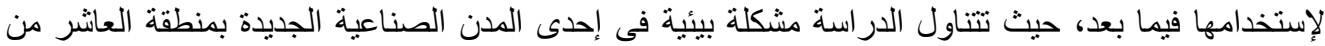

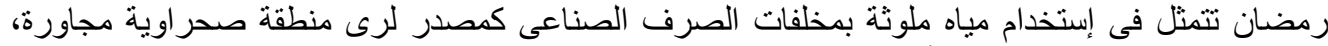

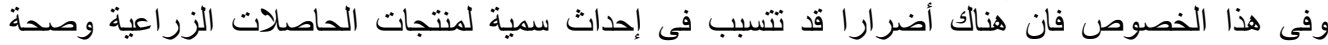

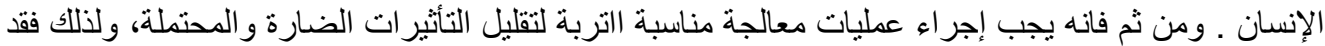

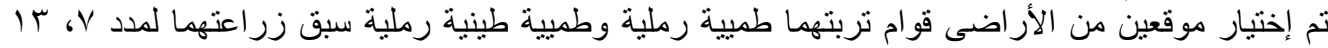

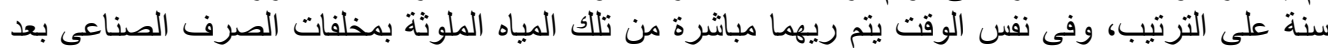

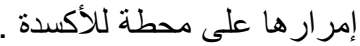

وتوضح النتائج المتحصل عليها إلى أن أر اضى تلك الموقعين قد تكونت من رسوبيات هو ائية وكلاهما

تنتمى إلى الوحدات التقسيمية التالية:

Typic Torriorthents, coarse or fine loamy, mixed, thermic.

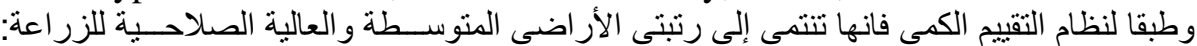
،Moderately (S2s1s3s4) and highly suitable (S1s1s3s4) for soil sites 1 and 2, respectively كما تسود بها بعض محددات لإنتاجية التربة ممثلة فى خاصية قو ام التربة،

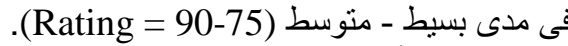
وقد أجرى تحليل كمى لإستبيان التركيب العنصرى لكل من التربتين تحت الدراسة، بجانب المياه

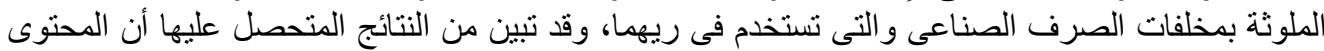

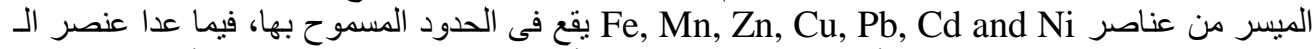

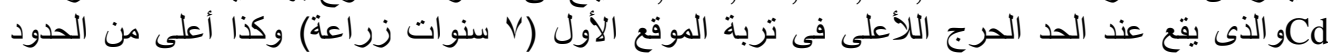

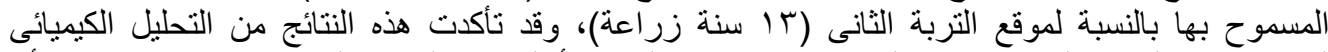

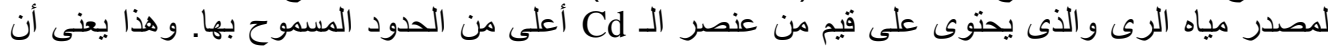

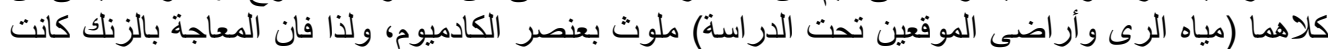

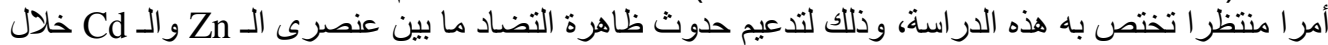

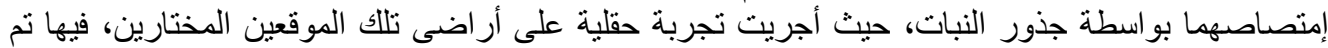

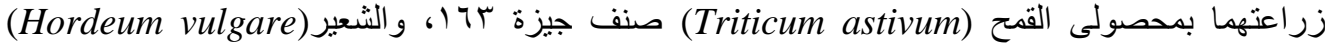

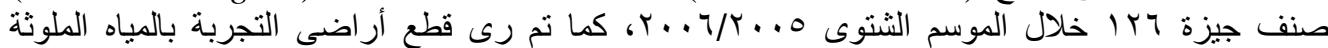

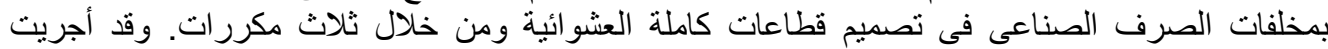

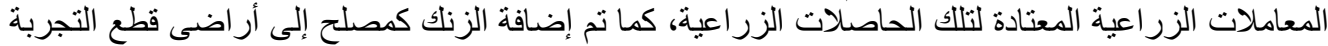

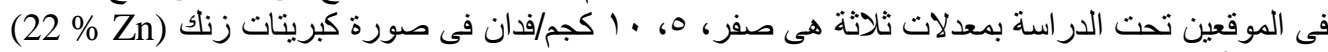
كإضافة أرضية.

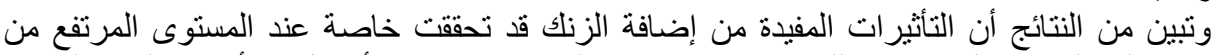

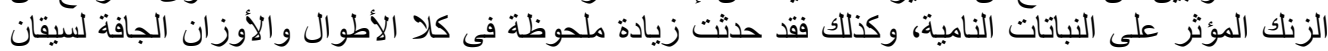

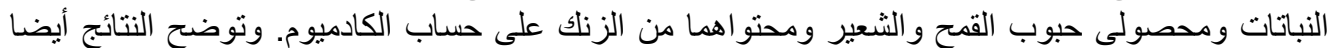

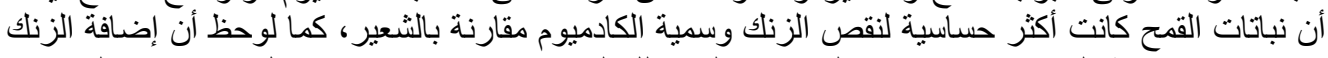

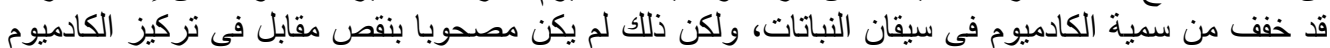

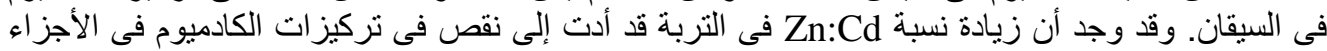

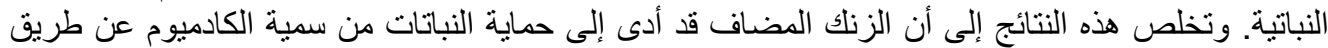

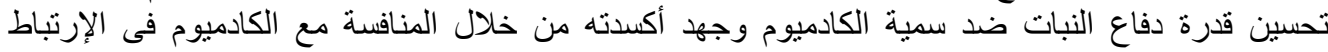

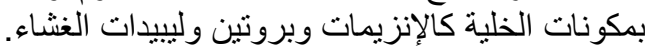

Fayoum J. Agric. Res. \& Dev., Vol. 21, No.1, January, 2007 